\title{
A Study on Role of Technology in Banking Sector
}

\author{
Aswin Raj. T ${ }^{1}$, Mr. Bala Nageshwara Rao ${ }^{2}$ \\ ${ }^{1}$ Student, ${ }^{2}$ Director \\ Saveetha School of Management, Chennai, Tamil Nadu
}

\begin{abstract}
The purpose of this study is to examine the relationship between new technology implementation in banking sector and customers. How they are aware about the technologies and how they are using it. Data for this study was collected from the customers of various Banking Sectors under the Reserve Bank of India. A simple percentage analysis and pie chart will be done. According to questioners 30 samples are collected and interpretations are given. Findings suggest that most of the customers of bank using ATM facility. So the banks need to give awareness about the E-banking services. Lastly, the paper is of few papers that focus on technology development in banking industry.
\end{abstract}

\section{Keyword: BANKING}

\section{INTRODUCTION}

The banking industry of India is in the midst of an Information technology revolution. A combination of regulatory and competitive reasons has led to increasing importance of total banking automation in this industry. Information technology has basically been used under different avenues in banking. One is communication and connectivity and another one is business process reengineering. Information technology enables difficult product development, better market infrastructure, implementation of reliable techniques for control of risks and helps the financial intermediaries to reach geographically distant and diversified markets.

Information technology has changed the contours of 3 major functions being performed by the banks i.e. access to liquidity, transformation of assets and then monitoring of risks. Further, information technology and the communication networking systems have a vital bearing on the efficiency of money, capital and foreign exchange markets.
The commercial banks went for Total Branch Automation Packages for computerization. The middle and late $90 \mathrm{~s}$ witnessed the storm of financial reforms, deregulation, globalization etc. coupled with rapid revolution in communication technologies and evolution of novel concept of convergence' of computer and communication technologies, like internet, mobile phones etc., It changed the face of Indian banking system completely.

\section{OBJECTIVES:}

$>$ To study the role of technology in banks.

To determine the technology in banks used by customers.

$>$ To analyse the banking innovations after computerisation of banks in India.

\section{RESEARCH METHODOLOGY:}

The study uses both primary and secondary data. The primary data has been collected from 50 respondents on the basis of convenient sampling. The samples were collected from customers of various banking sectors. The secondary data was collected from published sources such as journals, periodicals and websites

\section{TOOLS FOR THE STUDY:}

The analysis of data collected through research been done systematically. Simple percentage, pie chart and tables where used to represent variety of data that falls into various categories. The analysis has been done systematically and accurately so as to get correct and authentic.

\section{LIMITATION OF STUDY:}

My research has several limitations. This study was primarily limited by small sample size. The sample size could have been expanded. More contact between the researcher and respondents may have increased 
participation. A greater depth of information may have been obtained by conducting focus group. The respondents may have had a better understanding on CIBIL based on the questions included on the questionnaires. My methodology has included surveying or interviewing individuals involved with the respondents. The study could have added important qualitative data and greater insight into the respondents' thoughts and opinion

\section{SCOPE OF THE STUDY:}

The study covers the services offered by Banks to the customers by the use of technology. More specifically latest technological delivery channels, namely ATM/Debit card, Credit card, Internet Banking, Mobile Banking etc. have been taken up for the purpose of study. This project is an analytical study based on random sampling to ascertain the usage and satisfaction level and customer attitude towards these channels. The study also gives an idea of rendering secure, 24X7X365 E-banking services at a lower cost, without compromising with the quality thereby resulting in the widening of customer base.

\section{REVIEW OF LITERATURE}

Aggarwal (2003), in his paper, hunted for such avenues wherever e- banking may play important role in e-democracy. The author mentioned 2 case studies on the implementation of e-banking in digital democracy. One was farmer service and different was e-seva. Whereas applying e-banking in e-democracy, services become safer, efficient, clear and quick. It becomes a win-win state of affairs for all, for banks its low price, for presidency its higher service, for business it's quick and secure, and for voters its clear and economical. The author evaluated that e-banking might be used for thriving e-banking for online bill payment, online brokerage, online account management, anyplace banking, etc. The author terminated that e-banking services give one stop service and informational unit that gives nice advantages to banks, customers, employers and government.

Arora (2003) created an effort to prove that technology had a definitive role in facilitating transactions within the banking sector; and also the impact of technology had resulted into the introduction of recent product and services by varied banks in Asian nation. The author mentioned varied initiatives taken by the banks to manage transformation and these initiatives had brought customers the convenience of anyplace, anytime banking. The author ended that technology was a helper for advancement within the core business of banking ANd not an finish in itself.

Hogarth and Hilgert (2004) highlighted that electronic banking technology represents a spread of various services, starting from common ATM services and direct deposit to Automatic Bill Payment (ABP), Electronic Transfer of Funds (EFT) and pc banking (PC banking). the utilization of e-banking technologies had grownup chop-chop within the USA, whereas others are adopting it slowly. The authors explored such factors that have an effect on the adoption to adopt 3 e-banking technologies and changes in these factors over time. They advised that e-banking technologies couldn't be aggregate into one class, and thus, "one size fits all" wouldn't work. the utilization of e-banking depends upon however it helps in saving time, decrease the errors, up inaccurate accounting and preventing in manipulation of information.

Laforet and $\mathrm{Li}$ (2005), in their study investigated the market standing of online / mobile banking in China. the target of the study was to spot the target customers for online and mobile banking, and to match the angle of users and non-users towards e-banking with relevance variety of things like technology, security, convenience, etc. The authors selected a sample of three hundred respondents from six major cities of China. The results showed that online and mobile banking users were preponderantly males not essentially young and extremely educated. Security was the foremost vital issue that driven Chinese shopper for the adoption of on- line banking. however the most issues baby-faced by the shoppers of Chinese banks in on- line banking were perception of risks, laptop \& technological skills, and lack of awareness.

Ashiya (2006) evaluated developments created by electronic payments. The author evaluated completely different modes of e-payment used across the world. the most objective of the study was to seek out the present offerings and development provided by electronic payments. The author evaluated completely different modes of e-payment like plastic cards, debit cards, credit cards, sensible cards, electronic cheques etc. These electronic ways in which provided a wonderful instrument for payment system. The author analyzed that security was the most concern among electronic payments. However, e-payment this subtle technology may be used as a tool for the improvement 
of client loyalty and business of banks because it had reduced the danger \& value and will increase the client loyalty.

Enders et al.(2006), in their paper, self-addressed a basic downside of the troubled innovation theory that lies within the problem to categorise new technologies into sustaining and troubled innovation. The researchers 1st mentioned basic principles of troubled innovation theory, printed 5 main strategic diversions that incumbent companies ought to address once they face troubled circumstance in their business. They more mentioned completely different e- banking modes employed by Nordea banks, i.e., eidentification, e-signature services, e-billing services, e-salary performs, e-payment performs. However, ebanking services ought to be properly analyzed for the Einstein's theory of relativity of disruption.

Jain and Hundal (2006) represented the importance of mobile banking and barriers within the adoption of mobile banking. The paper examined the forces which will act as barriers in mobile banking service adoption. the target of the study was to seek out the explanations why the folks had not absolutely accepted the technology tho' it provided abundant advantage to the banking customers as compared to previous technologies. The paper tried to spot the varied barriers, viz. access issues, discontentedness and inability of service suppliers within the adoption of mobile banking services. The results of the study indicated that buyers got demoralized by the difficult perform whereas accessing the mobile banking services that cause rise in their discontentedness level, as no correct steerage was provided to them. The researchers instructed that service suppliers ought to bear in mind of the issues of their customers. The findings of the study gave a quick outlook for the sensible implication for managers and policy-makers United Nations agency have to be compelled to create ways and choices so as to cater the undiscovered service market.

Krishnamurthy (2006) highlighted the benefits, risks, innovations and convenience concerned in e-banking. ATM, telephone, web and cluster banking helped banks to deliver the merchandise a lot of effectively. The author, in his paper, conjointly delineated operational potency of e- banking. It enclosed basic ebanking, straightforward transactional and advanced transactional e- banking. Every website offered a differential reasonably services to customers. The author conjointly commented upon some risks like loss of secrecy of the shoppers, money stability, fraud prone potentialities, eruption of legal claims, etc. So, the author urged that banks ought to adopt such a technique during which risks and innovation in banking merchandise move parallel and at the same time.

Paul (2006) mentioned the role of technology and scope of remote channels, their implication, strength, weakness, chance and threat in banking sector. The author evaluated that IT development affects banking in 2 ways that. Firstly, it had contributed in reduction of prices related to management of knowledge by substitution paper based mostly and labour intensive strategies with automatic processes. Secondly, it had changed the ways that during which customers had access to banks' services and product. The man of science found that the introduction of RTGS, NDS, and CFMS had exaggerated the security, security, potency and soundness in payment system. Lastly, the author discovered that technology had a good impact on the structure of banking sector within the variety of bank branches, bank personnel and alliance.

Raghvan (2006) highlighted the transformation within the banking sector thanks to impact of knowledge technology, telecommunication and electronic processing. He conjointly tried to check the perception of banks in India within the year 2020 taking under consideration the impact of net banking, ATMs, newt on the performance of banks and initiative taken in easing, privatization and economic process. He conjointly evaluated the long run of online and net banking. Technology has modified the face of the Indian banking sector through automation. although the new non-public and foreign sector banks have a foothold at the present, however public sector banks have conjointly created a big progress during this regard. The analysis of the info collected from numerous banks has been done below the subsequent heads:

Raja et al. (2008) evaluated the impact of e-payment system on the business opportunities. They known that attributable to the expansion of net users, varied electronic payment mechanisms had been developed to cater the range of candidates. The researchers classified the e-payments into 3 main teams, namely, money like systems, check like systems, and hybrid systems that were any classified into credit cards, debit cards and electronic cheques. They known 
3main problems associated with e-payment that were security problems, low interest among businessman and serious reliance on ancient payment ways. They additionally analyzed that there have been technical and cultural issues that hinder the trail of e-payments. However, to form e-payments simpler, security threats ought to be reduced; and folk sought to be complete that ancient payment ways were longer intense than electronic payment ways. They ought to even be complete that plastic card payments were additional convenient, easier and safer than money or cheques.

\section{DATA ANALYSIS AND INTERPRETATION}

Table 1.1 showing the level of usage of technology

\begin{tabular}{|c|c|c|}
\hline Usage of technology & $\begin{array}{c}\text { No of } \\
\text { respondents }\end{array}$ & Percentage \\
\hline Financial transaction & 5 & $16.66 \%$ \\
\hline Stock exchange & 2 & $6.66 \%$ \\
\hline Online banking & 15 & $50 \%$ \\
\hline e -payments & 8 & $26.66 \%$ \\
\hline Total & 30 & $100 \%$ \\
\hline
\end{tabular}

Figure 1.1 showing the level of usage of technology LEVEL OF USAGE OFTECHNOLOGY
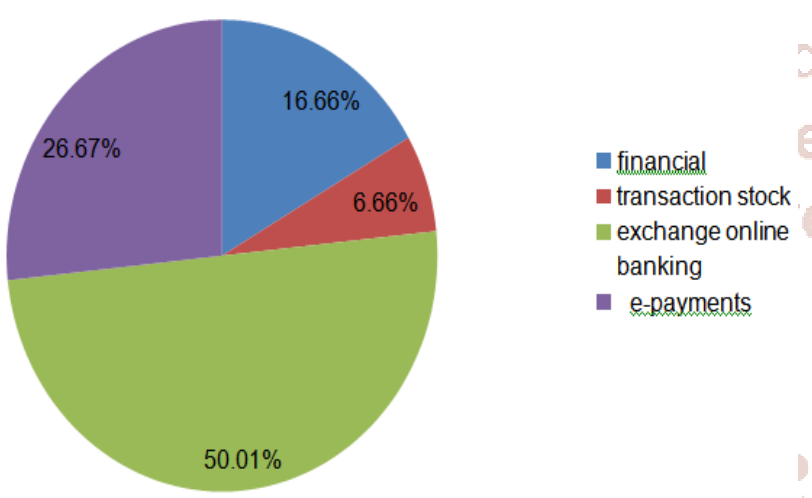

Source: primary data

According to the analysis done $50 \%$ of respondents use the technology for online banking, $26.66 \%$ of respondents use for e-payments, $16.66 \%$ for financial transactions and $6.66 \%$ of respondents use the technology in banking service for stock exchange.

Table 1.2 showing how frequently branch banking used per month

\begin{tabular}{|c|c|c|}
\hline $\begin{array}{c}\text { Branch banking use } \\
\text { per month }\end{array}$ & $\begin{array}{c}\text { No of } \\
\text { respondent }\end{array}$ & Percentage \\
\hline Nil & 3 & $10 \%$ \\
\hline 1 to 3 times & 16 & $53.33 \%$ \\
\hline 3 to 8 times & 8 & $26.66 \%$ \\
\hline 8 to 12 times & 1 & $3.33 \%$ \\
\hline Over 12 times & 2 & $6.66 \%$ \\
\hline Total & 30 & $100 \%$ \\
\hline
\end{tabular}

Figure 1.2 showing how frequently branch banking used per month BRANCH BANKING PER MONTH

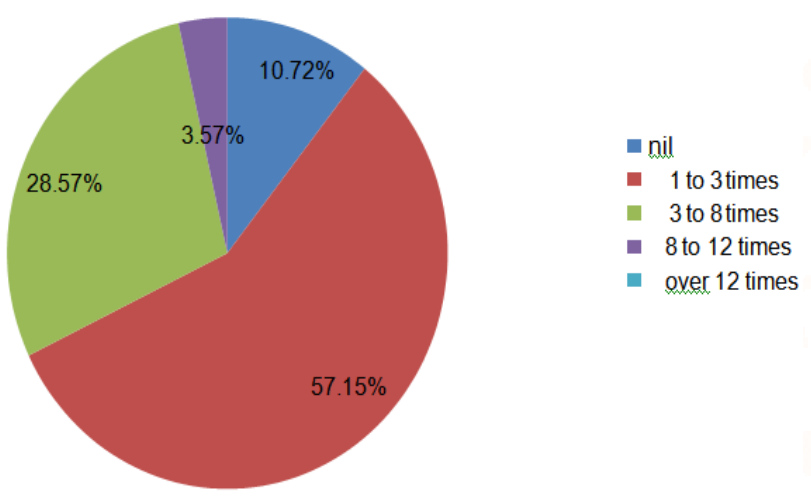

Source: primary data

Analysis shows that $10 \%$ of the respondents never visit their bank branch on a monthly basis. 53.33\% of respondents visit their banks between 1 to 3 times in a month. $26.66 \%$ of respondents visit their bank branch 3 to 8 times in a month and $3.33 \%$ of respondents visit their branch 8 to 12 times in a month. None of the respondents vist their bank more than 12 times a month.

Table 1.3 showing how frequently ATM used per month

\begin{tabular}{|c|c|c|}
\hline $\begin{array}{c}\text { A TM use per } \\
\text { month }\end{array}$ & $\begin{array}{c}\text { No of } \\
\text { respondent }\end{array}$ & Percentage \\
\hline Nil & 0 & $0 \%$ \\
\hline 1 to 3 times & 6 & $20 \%$ \\
\hline 3 to 8 times & 15 & $50 \%$ \\
\hline 8 to 12 times & 5 & $16.66 \%$ \\
\hline Over 12 times & 4 & $13.33 \%$ \\
\hline Total & 30 & $100 \%$ \\
\hline
\end{tabular}

Figure 1.3 showing how frequently ATM used per month ATM USE PER MONTH

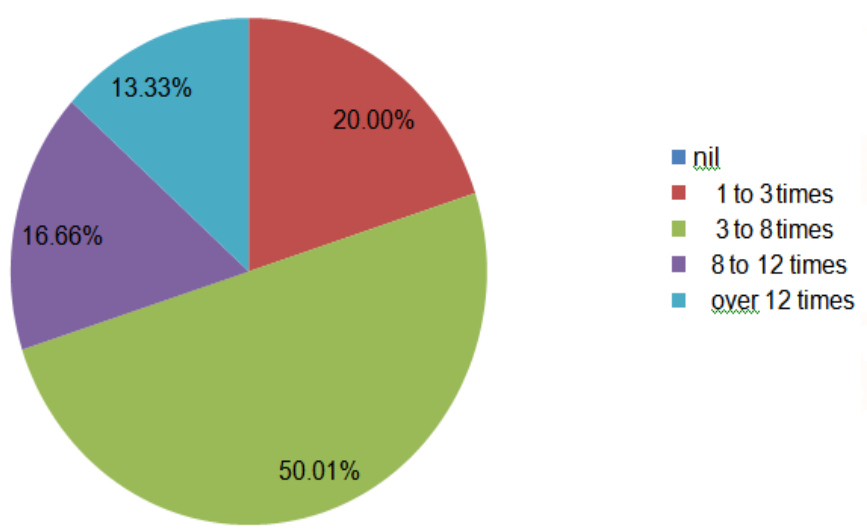

Source: primary data

Analysis shows that none of the respondents never visit their ATMs on a monthly basis. $20 \%$ of 
respondents visit their ATM 1 to 3 times in a month, $50 \%$ of respondents visit their ATM 3 to 8 times in a month, $16.66 \%$ of respondents visit ATM 8 to 12 times in a month and $13.33 \%$ of respondents visit the ATM over 12 times in a month.

Table 1.4 showing how frequently internet banking is used per month

\begin{tabular}{|c|c|c|}
\hline $\begin{array}{c}\text { Internet banking } \\
\text { use per month }\end{array}$ & $\begin{array}{c}\text { No of } \\
\text { respondent }\end{array}$ & Percentage \\
\hline nil & 3 & $10 \%$ \\
\hline 1 to 3 times & 12 & $40 \%$ \\
\hline 3 to 8 times & 6 & $20 \%$ \\
\hline 8 to 12 times & 5 & $16.66 \%$ \\
\hline Over 12 times & 4 & $13.33 \%$ \\
\hline total & 30 & $100 \%$ \\
\hline
\end{tabular}

Figure 1.4 showing how frequently internet banking is used per month INTERNET BANKING USE PER MONTH

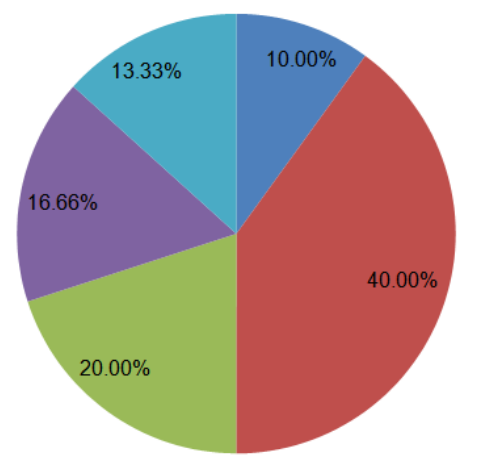
- nil
1 to 3 times
- 3 to 8 times
- 8 to 12 times
over 12 times

Source: primary data

According to the analysis done it shows $10 \%$ of respondents never use their internet banking on monthly basis, $40 \%$ of respondents use their internet banking 1 to 3 times in a month, 20\% of respondents use internet banking 3 to 8 times in a month, $16.66 \%$ of respondents use internet banking 8 to 12 times in a month and $13.33 \%$ of respondents use internet banking over 12 times in a month.

Tale 1.5 Showing reasons why E-banking services not used by most of the customer

\begin{tabular}{|c|c|c|}
\hline $\begin{array}{c}\text { E-banking services } \\
\text { not adopted }\end{array}$ & $\begin{array}{c}\text { Number of } \\
\text { respondents }\end{array}$ & Percentage \\
\hline Security risk & $\mathbf{1 2}$ & $40 \%$ \\
\hline $\begin{array}{c}\text { Prefer traditional } \\
\text { banking }\end{array}$ & $\mathbf{7}$ & $23.3 \%$ \\
\hline $\begin{array}{c}\text { Not aware of e- } \\
\text { banking }\end{array}$ & $\mathbf{5}$ & $16.6 \%$ \\
\hline $\begin{array}{c}\text { Some bank charge } \\
\text { high fees }\end{array}$ & $\mathbf{6}$ & $20 \%$ \\
\hline Total & 30 & $100 \%$ \\
\hline
\end{tabular}

Figure 1.5 Showing reasons why E-banking services not used by most of the customer E-BANKING SERVICES NOT ADOPTED

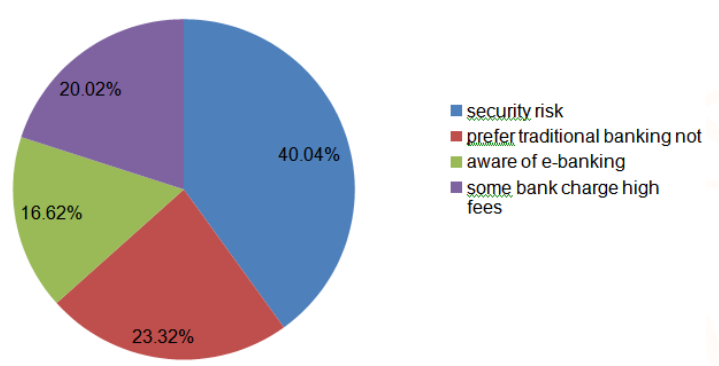

Source: primary data

According to this analysis $40 \%$ of respondents have not adopted E-Banking due to security risk. $23.30 \%$ of respondents prefer traditional Banking and $16.60 \%$ of respondents are not aware of e-banking. $20 \%$ of respondents consider that bank charges high fees for e-banking.

\section{FINDINGS:}

According to the study it was found that technology has paved a huge way for banking sector. A large number of respondents prefer E-Banking in the study region. A large number of respondents are satisfied with ATM facilities provided by banks. Majority of the respondents do not use Tele banking in the study region. A large number of respondents are benefited by paying utility bills by using Mobile Banking. Based on the study it was found that $90 \%$ of the respondents prefer using Internet Banking. A large number of respondents are satisfied with the level of Security provided by the bank; only $10 \%$ of the respondents are not satisfied according to the study conducted. Security threat is the possible reason why E-Banking services have not been adopted by the respondents. The study shows that majority of the respondents consider Private sector banks to be technologically advanced than Public sector banks. A large number of the respondents, rate the technology oriented services of the bank as good in the study region. Majority of the customers have opined that bank's operation is efficient after the introduction of computers in the banks.

\section{SUGGETIONS:}

$>$ The bank needs to give awareness to customers about internet banking.

Most of the customers are feeling risk in Ebanking so the banking industry needs beliminate those risks.

\section{CONCLUSION}

Technology today has become integral to the business of banking; it is difficult to envision one without the 
other. However as with other resources it has costs attached to it and with substantial investments in IT infrastructure business leaders will have to seek answers to whether the infrastructure is being used optimally.

Technology have to be client centrically to derive optimum edges and banks can got to equally target client retention and increasing share of case instead of solely acquisition. for many of banking customers going back to their primary bank for the other new relationship could be a major challenge. This can be attributable to the insufficiency of CRM and atomic number 83 solutions. Knowledge integration of client interaction through multiple channels remains not on the market to side branch personnel. With redoubled use technology additionally comes redoubled risk of security breaches. Banks can got to on their toes with real time alert systems and governance policies to manage the threats for early detection and control. The longer term IT vision and strategy of banks can got to balance price delivered to the firm. It'll got to be aligned to the strategic objectives of the firm and be in command of the delivering desired price.

To achieve this difficult task of satisfying the customers, the banks area unit turning towards the technology for the assistance. Technology has been one among the foremost necessary factors for the event of human beings. Information and communication technology is that the major advent within the field of technology that is employed for access, process, storage and dissemination of data electronically. industry is quick growing with the employment of technology within the variety of ATMs, online banking, SMS banking, Mobile banking etc., plastic card is one among the banking merchandise that cater to the wants of retail section has seen its range grow in patterned advance in recent years. Net has compete a many opportunities for players within the banking sector. Whereas the new entrants have the advantage of latest technology, the goodwill of the established banks offers them a special chance to steer the net world.

\section{BIBLIOGRAPHY}

Aggarwal (2003), in his paper, looked for such avenues where e-banking could play significant role in e-democracy

Arora (2003) made an attempt to prove that technology had a definitive role in facilitating transactions in the banking sector; and the impact of technology had resulted into the introduction of new products and services by various banks in India.
Laforet and Li (2005), in their study investigated the market status of online / mobile banking in China.

Ashiya (2006) evaluated developments made by electronic payments. The author evaluated different modes of e-payment used across the globe.

Enders et al. (2006), in their paper, addressed a fundamental problem of the disruptive innovation theory which lies in the difficulty to categorize new technologies into sustaining and disruptive innovation.

Jain and Hundal (2006) described the importance of mobile banking and barriers in the adoption of mobile banking.

Krishnamurthy (2006) highlighted the advantages, risks, innovations and convenience involved in ebanking. ATM, telephone, internet and cluster banking helped banks to deliver the products more effectively.

Paul (2006) discussed the role of technology and scope of remote channels, their implication, strength, weakness, opportunity and threat in banking sector.

Raghvan (2006) highlighted the transformation in the banking sector due to effect of information technology, telecommunication and electronic data processing.

Raja et al. (2008) evaluated the impact of e-payment system on the business opportunities.

Sarangapani and Mamtha (2008b) studied the impact of Information Technology on banking sector and its security related aspects.

Uppal R.K. (2010) studies the extent of mobile banking in Indian banking industry during 20002007. The study concludes that among all e-channels.

Hua G. (2009) investigates the online banking acceptance in China by conducting an experiment to investigate how users' perception about online banking is affected by the perceived ease of use of website and the privacy policy provided by the online banking website.

Sharma M.C. and Sharma Abhinav: Reported that Indian public sector banks that hold around $75 \%$ of market share do have taken initiative in the field of IT.

Sreelatha $\mathbf{T}$ and Chandra Shekhar Reveled: That Technology has charged the face of the Indian banking sector through computation, while new private sector banks and foreign banks have an edge in this regard.

Bradley and Stewart (2003): Nearly every bank will have technology services available by the year 2011 . 